The University of Maine

\title{
DigitalCommons@UMaine
}

Earth Science Faculty Scholarship

Earth Sciences

1982

\section{Geochemical and Glacio-geomorphic Implications of Basalt Weathering in the Queen Maud Mountains, Antarctica}

R. W. Talkington

Paul Andrew Mayewski

University of Maine, paul.mayewski@maine.edu

H. E. Gaudette

Follow this and additional works at: https://digitalcommons.library.umaine.edu/ers_facpub

Part of the Geomorphology Commons, Glaciology Commons, Hydrology Commons, and the Sedimentology Commons

\section{Repository Citation}

Talkington, R. W.; Mayewski, Paul Andrew; and Gaudette, H. E., "Geochemical and Glacio-geomorphic Implications of Basalt Weathering in the Queen Maud Mountains, Antarctica" (1982). Earth Science Faculty Scholarship. 202.

https://digitalcommons.library.umaine.edu/ers_facpub/202 


\title{
Geochemical and glacio-geomorphic implications of basalt weathering in the Queen Maud Mountains, Antarctica
}

\author{
R. W. TALKINGTON, P. A. MAYEWSKI \& H. E. GAUDETTE
}

(Plates 1-2)

Summary. The weathering of a suite of basalt clasts, that have been transported by mass wasting downslope in the Cumulus Hills region of the Queen Maud Mountains, Antarctica, is examined from both geochemical and glacio-geomorphic viewpoints. Chemical weathering. predominantly oxidation and hydration. increases in severity from clast core to rim for the suite. These weathering processes and concomitant formation of a weathering rind are suggested to be an accumulative process, culminating in the disaggregation of the rock due in part both to the chemical breakdown of the interstitial and intersertal basaltic glass and to physical weathering processes.

Mass wasting rates in the range of $1.4 \times 10^{-3} 1.13 \times 10^{-1} \mathrm{~cm} \cdot \mathrm{y}^{-1}$ are estimated, assuming that the style of transport is dry creep. These transport rates suggest that the rock-surface/air-temperature differences in the study area may have been as little as $0.5^{\circ} \mathrm{C}$ and heating and cooling cycles as few as $1 \mathrm{cy} \cdot \mathrm{y}^{-1}$ for the last $4.2 \mathrm{Ma}$.

\section{Introduction}

The formation of weathering rinds on rocks and soil profiles has been ascribed to various physical, chemical and biological processes (Claridge \& Campbell, 1968; Cooke \& Smalley, 1968; Jackson \& Keller, 1970; Singer \& Navrot, 1970; Fritz \& Ragland, 1980; Colman \& Pierce, 1981). These studies and others have shown that moisture and temperature are the most important variables which affect weathering. For example, Birkeland (1974) indicated that moisture and temperature have a pronounced effect on leaching and on chemical and biological reaction rates, respectively, such that a combination of high humidity and temperature accelerates rock and soil weathering processes. However, low humidity combined with constant or variable temperature retards the rock and soil weathering processes where an increase in temperature decreases the moisture content of the rock/soil (cf. Colman \& Pierce, 1981).

The severity of East Antarctica provides an interesting environment to study rock weathering processes in an 'arid' climate. A suite of basalt clasts from a single dike source from the Cumulus Hills region provides data on geochemical and physical weathering processes and rock transport mechanisms in this environment.

\section{Location and site description}

Halfmoon Bluff is located in the northern Cumulus Hills (Plate 1) of the Queen Maud Mountains, East Antarctica. The study site at Halfmoon Bluff is a $60 \mathrm{~m}$ long by $2 \mathrm{~m}$ wide slope. The slope forms the east-facing side of a cuesta-like feature, approximately $1900 \mathrm{~m}$ above sea level, formed by a $3 \mathrm{~km}$ long NW-SE trending, near-vertical basaltic dike. The dike is several metres wide and forms the source area for the $60 \mathrm{~m}$ length of basalt clast scree investigated in this study. This scree overlies highly disrupted mudstones and sandstones of the Fremouw Formation. Downslope movement of the sediments underlying the basalt clasts has apparently led to their dispersal. Clasts most recently exfoliated from the dike and lying closest to it are the least weathered, while those dispersed farther downslope are progressively more weathered. Approximately half the area of the northern

Geol. Mag. 119 (6), 1982. pp. 55.3566. Printed in Great Britain. 
Cumulus Hills including Halfmoon Bluff is currently ice-free. Shackleton Glacier, two of its tributary glaciers and highland ice, flank the borders of this ice-free area.

\section{Local climate and geomorphic setting}

The climate of the Halfmoon Bluff area is largely dominated by the intense katabatic winds that descend from the Polar Plateau northwestward down Shackleton Glacier and towards the coast. Mean annual snow balance for the area is approximately $10-20 \mathrm{~g} . \mathrm{cm}^{2}$. $\mathrm{y}^{1}$ (Bull, 1971). Most of this precipitation is derived from the coast. though small amounts of wind-blown snow are also carried into the area from the southeast by katabatic winds. Although mean annual temperature is approximately -30 to $-35^{\circ} \mathrm{C}$ (Weyant, 1967) and meltwater not common, there are usually several days during each summer season when small streams can be observed at the contact between ice and bedrock.

Although local climatic conditions play an important role in the development of geomorphic features in Antarctica, the Halfmoon Bluff study site has been chosen so as to minimize microclimate effects. The site is small $(60 \mathrm{~m} \times 3 \mathrm{~m})$, vertical relief of the slope is small $(16.3 \mathrm{~m})$, all segments of the slope face the same direction $\left(\mathrm{N} 7^{\circ} \mathrm{E}\right)$ and the clasts examined are all of similar size and lithology.

Weathering rates differ primarily as a function of lithology (Behling, 1971, Ph.D. Thesis, Ohio State University; Birkeland, 1974). In the study area, basalt clasts comprise the most resistant lithology, and sandstones and mudstones the least resistant lithologies. Due to their high relative resistance to weathering and disaggregation the basalt clasts record a long history of exposure. The source dike for the basalt clasts is relatively free of weathering effects, as evidenced by fresh surfaces along columnar joint planes of the dike.

The basalt clasts in this study have been dispersed throughout the study slope by mass wasting. Slope angles in the study area range from $9^{\circ}$ to $23^{\circ}$ (average $15.2^{\circ}$ ). Low mean annual temperature, low precipitation and continual sublimation minimize the likelihood of mass wasting due to water and/or ice saturation in this area. Therefore, mechanisms of mass wasting such as gravity-induced sliding and creep generated by heating and cooling of rock surfaces appear to be dominant.

\section{Sample description}

\section{4.a. Physical description of basalt clasts}

The eight basalt specimens collected at Halfmoon Bluff display a continuum from fresh to highly weathered. Details concerning each of these samples including distance downslope from source, dimensions, weathering classification and general description appear in Table 1. The specimens have been divided visually based on surface weathering characteristics into three categories, fresh to mildly weathered (specimens HM-1, 2 and 3), moderately weathered (samples HM-4, 5 and 6) and highly weathered (specimens HM-7 and 8). It can be seen from Table 1 that with distance from their source the basalt clasts decrease in angularity with a corresponding increase in edge rounding and pitting (maximum pit depth $10 \mathrm{~mm}$ ) as their surfaces become more oxidized (Fig. 1). Although zone-weathering thicknesses vary for most samples (Fig. 2), it is possible to distinguish the top and bottom of a clast by simple inspection of the depth of penetration of weathering. Alternatively, the development or partial development of tafoni on the top surface of a clast or the accumulation of a salt or carbonate rind encrusting the base of a clast aids in a rapid, yet tentative, field identification of clast top and bottom. This visual method is not applicable to clasts that have a clast-substrate to surface area contact ratio less than or equal to one. 
Table 1. Physical characteristics of samples

\begin{tabular}{|c|c|c|c|}
\hline Sample & $\begin{array}{l}\text { Distance } \\
\text { downslope from } \\
\text { source area }(\mathrm{m})\end{array}$ & $\begin{array}{l}\text { Weathering } \\
\text { classification* }\end{array}$ & Description of sample surfaces \\
\hline HM-1 & 2 & $\mathrm{Ab} \dagger$ & $\begin{array}{l}\text { Thin, patchy } \mathrm{CaCO}_{3} \text { residue. Windward-oriented surfaces } \\
\text { slightly roughened while non-windward are smooth. Bright } \\
\text { red-brown coloration on all surfaces. }\end{array}$ \\
\hline HM-2 & 8 & $\mathrm{Ab}$ & Same as HM-1, but fracture edges and clast edges rounded. \\
\hline HM-3 & 11.5 & $\mathrm{Ab}$ & Same as $\mathrm{HM}-2$, but windward surface roughening more intense. \\
\hline HM-4 & 14 & $\mathrm{Be}$ & $\begin{array}{l}\text { Same as HM-3, but fracture and clast edges more rounded. } \\
\text { Roughly circular pits, maximum depth } 1 \mathrm{~mm} \text { present along } \\
\text { fractures and windward faces. }\end{array}$ \\
\hline HM-5 & 25 & $\mathrm{Be}$ & $\begin{array}{l}\text { Same as HM-4, but maximum pit depth increased to } 2 \mathrm{~mm} \text {. } \\
\text { Light red-brown residue localized in pit bottoms. } \\
\text { Non-windward surfaces still fairly smooth. }\end{array}$ \\
\hline HM-6 & 30 & $\mathrm{Be}$ & $\begin{array}{l}\text { Same as HM-5, but maximum pit depth increased to } 3 \mathrm{~mm} \text {. } \\
\text { Some pits are elongated. }\end{array}$ \\
\hline HM-7 & 44 & $\mathrm{Be}$ & $\begin{array}{l}\text { Same as HM- } 6 \text {, but clast edges more rounded, pits coalesced } \\
\text { and lineated with maximum pit depth } 7 \mathrm{~mm} \text {. Non-windward } \\
\text { surfaces roughened. }\end{array}$ \\
\hline HM-8 & 60 & $\mathrm{Be}$ & $\begin{array}{l}\text { Same as } \mathrm{HM}-7 \text {, but maximum pit depth increased to } 10 \mathrm{~mm} \text {. } \\
\text { Pits cover windward surfaces and adjacent clast edges. }\end{array}$ \\
\hline
\end{tabular}

* Symbols as designated using Queen Maud Mountains weathering classification (Mayewski, 1975; Mayewski \& Goldthwait, in the Press). A, Fresh (unweathered) sharp surfaces, angularity due to fracturing. B, Edges of clast no longer sharp. E, Pits $1 \mathrm{~cm}$ or less in depth.

$\dagger$ Order of letters denotes relative importance of characteristic; small-letter designations denote incipient characteristics.
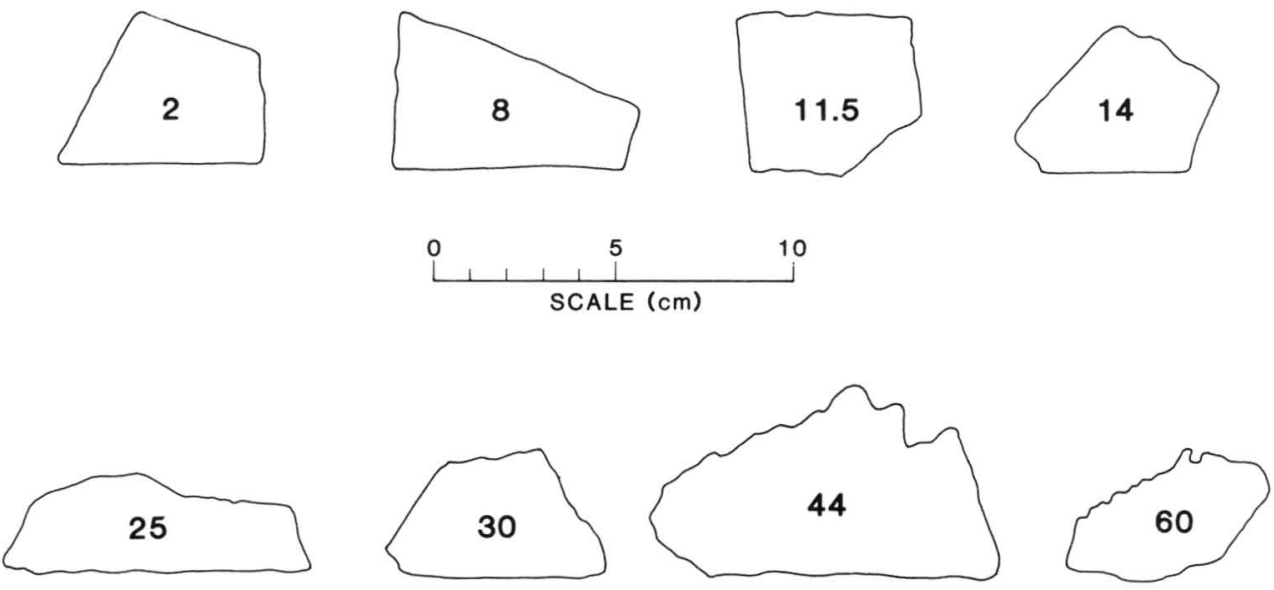

Figure 1. Cross-sectional view of basalt clasts with field orientations maintained. Distance from ridge crest in metres is marked on specimens. Note that specimen at $11.5 \mathrm{~m}$, based on its shape and surface features, may have been recently rotated.

This metastable configuration may enable physical processes to tumble a clast along the slope surface (e.g. specimen at $11.5 \mathrm{~m}$, Fig. 1).

Preliminary observations of carbonate rinds on the base of clasts (see Table 1) suggest that they protect or buffer the rock against penetrative weathering. The weathering rind is much thinner on specimens which contain a carbonate crust (Table 1; Fig. 2). Colman \& Pierce (1981) also identified a similar relationship for specimens collected from a site near 


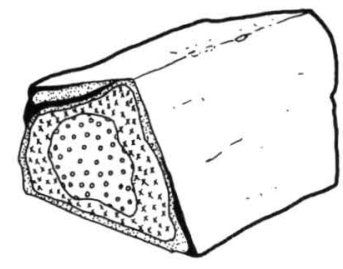

$H M-I \quad 2 m$

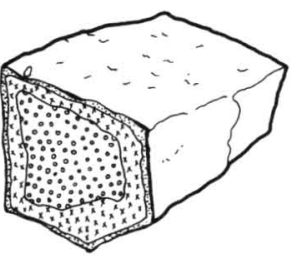

$H M-3 \quad 11.5 m$

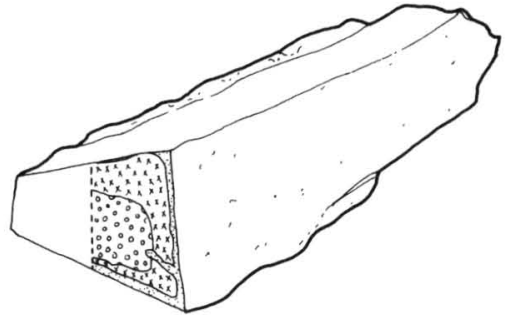

$\mathrm{HM}-2 \quad 8 \mathrm{~m}$

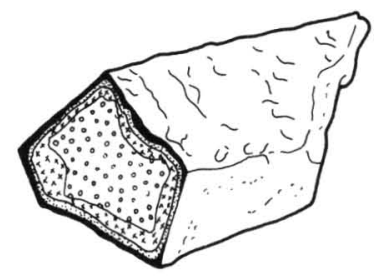

$\mathrm{HM}-4 \quad 14 \mathrm{~m}$

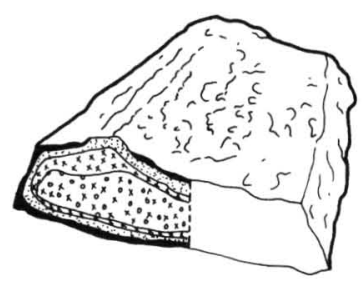

HM- $525 \mathrm{~m}$

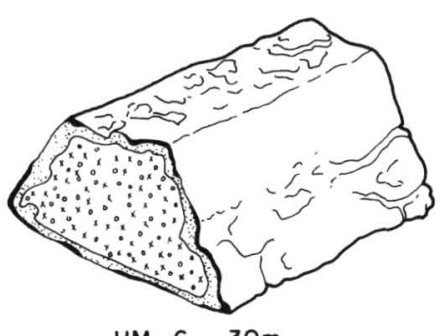

HM- $630 \mathrm{~m}$

Figure 2. Prospective drawings and cross-sectional views of basalt clasts. Relative age of exposure increases from HM-1 $(2 \mathrm{~m})$ to HM-8 $(60 \mathrm{~m})$. Note increase with distance downslope in (1) roundness; (2) thickness in weathering zones; (3) development of tafoni.

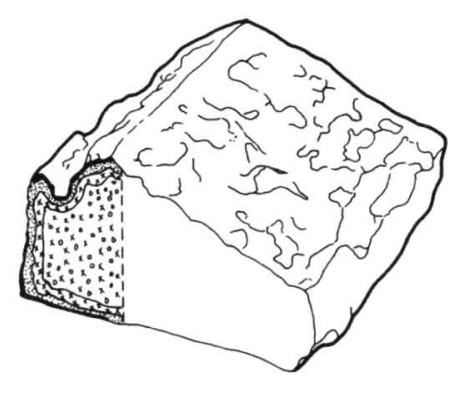

HM-7 $44 m$

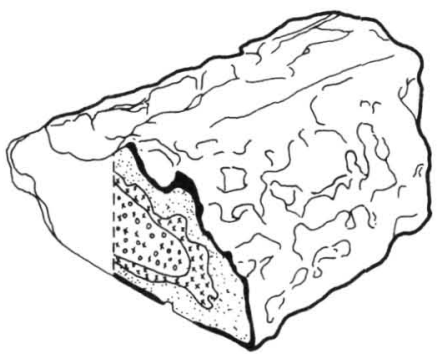

$\mathrm{HM}-8 \quad 60 \mathrm{~m}$ WEATHERING ZONES

zone 5 most weathered ZONE 4

ZONE 3

ZONE 2

ZONE 1 FRESH SCALE $\mathrm{cm}$

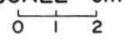


Hardin, Montana. Those parts coated with calcium carbonate show limited effects of penetrative weathering.

\section{4.b. Microscopic description of weathering zones}

The criteria for distinguishing the various weathering zones utilize the colour of the stain, its intensity and concentration and mineral phases (including the glass phases) effected by the staining (Talkington, Gaudette \& Mayewski, 1976). All observations and measurements have been determined from thin sections made from rock slabs cut through the centre of the specimens (Fig. 2). Each zone varies in thickness, intensity of weathering and distribution of staining of the mineral and glass phases. The boundaries between zones, especially the less weathered zones, are often diffuse.

The microscopic description of each weathering zone is defined as follows (see Fig. 2). Zone 1 - fresh, no alteration of plagioclase or augite; slight discolouration (light brown) of glass.

Zone 2 -slight discolouration of silicate minerals; augite shows a light green colouration of core; plagioclase is usually unaltered; glass phases are orange-red.

Zone 3 - augite core green to yellow-red colour; plagioclase slightly discoloured from iron stain; glasses are light red-orange.

Zone 4-light red-brown (burnt-orange) colouration of the glass and the augite core; minor alteration of plagioclase core (smectities?) and slight discolouration from iron stain. Zone 5-dark red-brown colouration of the glass and augite core; extensive red-brown iron staining on plagioclase.

Zones 1 and 2 occur together in the cores of the least altered specimens; however, as total specimen alteration increases (HM-1 to $\mathrm{HM}-8$ ), the specimen core becomes progressively more altered (e.g. HM-1, core Zone 2; HM-6, core Zone 2-3; HM-8, core Zone 2-3, dominantly Zone 3 ). Zone 3 is the most areally extensive zone, occurring between Zones 2 and 4.

\section{Results and interpretation}

\section{5.a. Petrography}

The clasts are identical in microscopic and mineral chemical character and are a typical tholeiitic basalt. The texture is diabasic and the average grain size is $0.15-0.20 \mathrm{~mm}$. Approximately equal quantities of idiomorphic and rare skeletal plagioclase and anhedral to euhedral subcalcic augite are enclosed in a devitrified basaltic glass and tholeiitic rhyolite matrix (Plate 2a). Minor quantities of Fe-Ti oxides occur as a discrete groundmass phase or disseminated within the devitrified glass as rods or platelets. Vesicles filled by chlorite and quartz are rare.

Plagioclase is unaltered in most samples. In all specimens, plagioclase cores appear to be filled with a nearly opaque material (Plate $2 \mathrm{~b}$ ). Microprobe analysis of this material (Table 2) from several acicular grains yields results resembling the chemistry of basaltic glass (see Table 5 for comparison). These results are partly contaminated with plagioclase due to the small size of these glass regions. Iron-oxide platelets (haematite?), sometimes hexagonal, are present along fractures in plagioclase. These fractures are 'traps' for surface iron coating.

Sulcalcic augite occurs in two distinct habits: as subhedral-anhedral and euhedral cross-sections (001). The subhedral-anhedral type is generally unaltered, but incipient hydration to 'uralite' or chlorite along grain edges is observed. Within euhedral cross-sections twinning (100) is developed. Core regions are invariably altered to chlorite(?) (Plate 2a). 
Table 2. Electron microprobe analyses of intersertal basaltic glass in plagioclase cores

\begin{tabular}{lrrrr}
\hline & \multicolumn{1}{c}{1} & \multicolumn{1}{c}{2} & \multicolumn{1}{c}{4} \\
\hline $\mathrm{SiO}_{2}$ & 46.13 & 49.09 & 41.21 & 44.87 \\
$\mathrm{TiO}_{2}$ & 0.21 & 0.30 & 0.15 & 0.07 \\
$\mathrm{Al}_{2} \mathrm{O}_{3}$ & 20.97 & 18.07 & 11.30 & 21.76 \\
$\mathrm{FeO}^{*}$ & 16.26 & 8.61 & 22.19 & 10.81 \\
$\mathrm{MnO}$ & 0.21 & 0.17 & 0.31 & 0.18 \\
$\mathrm{MgO}$ & 6.13 & 3.97 & 11.55 & 5.11 \\
$\mathrm{CaO}$ & 6.76 & 9.11 & 10.24 & 6.07 \\
$\mathrm{Na}_{2} \mathrm{O}$ & 2.43 & 1.45 & 0.14 & 2.22 \\
$\mathrm{~K}_{2} \mathrm{O}$ & 1.40 & 6.59 & 2.44 & 2.03 \\
Total & 100.50 & 97.36 & 99.53 & 93.12 \\
\hline
\end{tabular}

$1 \mathrm{HM}-2.1$, core of plagioclase grain. $2 \mathrm{HM}-2.2$, core of plagioclase grain. $3 \mathrm{HM}-6.1$, core of plagioclase grain. 4 HM-6.2, core of plagioclase grain.

The microscopic appearance of the devitrified basaltic glass changes from the core to the rim of clasts. Observations with transmitted light indicate a change in intensity of coloration (faint tan-brown to bright red-brown) from core to rim. Although variations in the distribution of glass coloration are recognized throughout any given slide, disseminated oxides within the glass do not vary from core to rim of the clasts.

\section{5.b. Mineral chemistry}

In order to evaluate what phase or phases are responsible for producing the weathered rinds, all major mineral phases have been analysed by electron microprobe. To do this, regions on the slides have been isolated which are representative of individual weathering zones. Spot chemical analyses by electron microprobe have been determined from each region. For mineral phases, the analyses have been performed on specimens HM-1 (2 m), HM-2 (8 m), HM-6 (30 m) and HM-8 (60 m).

Representative electron microprobe analyses of plagioclase and pyroxene from core (least weathered) to rim (most weathered) are listed in Tables 3 and 4, respectively. Analytical methods are given in the Appendix. The data show no variation from the freshest to most weathered parts of a clast. As a consequence, we are not able to quantify the degree of element leaching of these minerals during weathering. However, in areas of high interstitial basaltic glass concentrations plagioclase grains and other phases closely associated with glass show a higher relative degree of iron staining, especially in Zones 2 and 3. Iron staining in Zones 4 and 5 is less concentrated adjacent to abundant basaltic glass areas.

Microprobe analyses of interstitial altered basaltic and tholeiitic rhyolitic glasses from this study are listed in Table 5. Because no unaltered basaltic glass remains to determine the chemical participation of the glasses in rind development, we have compared them to unaltered and altered glasses from oceanic (Muffler et al. 1969; Melson, 1973; Thompson, 1973; Melson et al. 1975) and continental studies (Singer \& Navrot, 1970; Leeman \& Vitaliano, 1976; Bain et al. 1980).

Thompson (1973) indicated that alteration of basalt glass from the rims of pillowed lava dredged from the Mid-Atlantic Ridge proceeds with an increase in $\mathrm{H}_{2} \mathrm{O}(0-20$ wt. \%), total iron, $\mathrm{Al}$ and $\mathrm{K}$ and a depletion of $\mathrm{Ca}$ and Si. Melson (1973), however, reported only a minor increase in $\mathrm{K}$ and slight depletion in $\mathrm{Si}, \mathrm{Al}$ and total iron for submarine basalt flows. In a geochemical study of fresh and altered basaltic glass fragments in an aquagene tuff from Hound Island, Alaska, Muffler et al. (1969) found that $\mathrm{Si}, \mathrm{K}$ and $\mathrm{H}_{2} \mathrm{O}$ increase, whereas $\mathrm{Mg}, \mathrm{Ca}, \mathrm{Fe}^{2+}$ and $\mathrm{Mn}$ decrease due to alteration as a result of hydration. 
Table 3. Representative microprobe analyses of plagioclase

\begin{tabular}{lcrrrrrrr}
\hline & 1 & \multicolumn{1}{c}{2} & \multicolumn{1}{c}{3} & \multicolumn{1}{c}{4} & \multicolumn{1}{c}{5} & 6 & 7 & \multicolumn{1}{c}{8} \\
\hline $\mathrm{SiO}_{2}$ & 52.02 & 53.34 & 54.47 & 58.48 & 52.71 & 53.06 & 52.06 & 52.64 \\
$\mathrm{TiO}_{2}$ & 0.05 & 0.06 & 0.08 & 0.07 & 0.04 & 0.02 & 0.01 & 0.05 \\
$\mathrm{Al}_{2} \mathrm{O}_{3}$ & 29.57 & 28.83 & 26.53 & 25.58 & 29.53 & 28.49 & 29.57 & 28.61 \\
$\mathrm{FeO}^{*}$ & 0.96 & 0.77 & 1.18 & 0.72 & 0.95 & 1.13 & 0.64 & 0.91 \\
$\mathrm{MnO}$ & - & - & 0.01 & - & 0.06 & 0.05 & 0.01 & 0.04 \\
$\mathrm{MgO}$ & 0.22 & 0.28 & 0.19 & 0.12 & 0.29 & 0.19 & 0.45 & 0.30 \\
$\mathrm{CaO}$ & 13.91 & 13.70 & 12.18 & 9.31 & 13.67 & 13.77 & 14.81 & 13.84 \\
$\mathrm{Na} 2$ & 3.39 & 3.42 & 4.48 & 5.87 & 3.32 & 3.27 & 2.78 & 3.35 \\
$\mathrm{~K}_{2} \mathrm{O}$ & 0.25 & 0.26 & 0.40 & 0.28 & 0.29 & 0.27 & 0.21 & 0.27 \\
$\mathrm{Total}$ & 100.37 & 100.66 & 99.52 & 100.43 & 100.86 & 100.25 & 100.54 & 100.01 \\
$\mathrm{An}$ & 68.3 & 68.0 & 58.7 & 45.9 & 68.4 & 68.9 & 73.7 & 68.5 \\
\hline
\end{tabular}

- Not detected.

* All $\mathrm{Fe}$ was calculated as $\mathrm{FeO}$.

$1 \mathrm{HM}-1$, outer rim of clast. $2 \mathrm{HM}-1$, core region of clast. $3 \mathrm{HM}-2$, outer rim of clast. $4 \mathrm{HM}-2$, core region of clast. 5 HM-6, outer rim of clast. $6 \mathrm{HM}-6$, core region of clast. $7 \mathrm{HM}-8$, outer rim of clast. $8 \mathrm{HM}-8$, core region of clast.

Table 4. Representative pyroxene microprobe analyses

\begin{tabular}{lcccccccc}
\hline & 1 & \multicolumn{1}{c}{2} & \multicolumn{1}{c}{3} & \multicolumn{1}{c}{4} & \multicolumn{1}{c}{5} & \multicolumn{1}{c}{6} & \multicolumn{1}{c}{7} & \multicolumn{1}{c}{8} \\
\hline $\mathrm{SiO}_{2}$ & 50.88 & 52.37 & 52.50 & 53.21 & 52.73 & 52.03 & 53.24 & 50.99 \\
$\mathrm{TiO}_{2}$ & 0.45 & 0.26 & 0.41 & 0.32 & 0.27 & 0.28 & 0.15 & 0.25 \\
$\mathrm{Al}_{2} \mathrm{O}_{3}$ & 2.21 & 2.22 & 2.59 & 2.08 & 2.06 & 2.20 & 1.98 & 2.25 \\
$\mathrm{FeO}^{*}$ & 9.78 & 8.49 & 10.37 & 9.60 & 9.15 & 8.67 & 10.05 & 9.05 \\
$\mathrm{MnO}$ & 0.23 & 0.20 & 0.25 & 0.22 & 0.18 & 0.20 & 0.21 & 0.23 \\
$\mathrm{MgO}$ & 15.75 & 20.89 & 17.01 & 20.46 & 20.82 & 19.50 & 21.30 & 20.63 \\
$\mathrm{CaO}$ & 20.39 & 15.29 & 16.89 & 14.08 & 14.23 & 16.84 & 13.55 & 15.38 \\
$\mathrm{Na}$ & 0.18 & 0.12 & 0.57 & 0.14 & 0.07 & 0.14 & 0.09 & 0.11 \\
$\mathrm{~K}_{2} \mathrm{O}$ & 0.01 & 0.02 & - & - & 0.01 & - & - & - \\
$\mathrm{Cr}_{2} \mathrm{O}_{3}$ & - & 0.23 & - & 0.04 & 0.15 & 0.16 & 0.10 & 0.16 \\
$\mathrm{Total}$ & 99.88 & 100.09 & 100.59 & 100.15 & 99.67 & 100.02 & 100.67 & 99.05 \\
$\mathrm{Ca}: \mathrm{Mg}: \mathrm{Fe}$ & $41: 44: 15$ & $30: 57: 13$ & $35: 49: 16$ & $31: 56: 13$ & $28: 58: 14$ & $33: 54: 13$ & $27: 58: 15$ & $30: 56: 14$ \\
\hline
\end{tabular}

- Not detected.

* All Fe was calculated as $\mathrm{FeO}$.

$1 \mathrm{HM}-1$, outer rim of clast. $2 \mathrm{HM}-1$, core region of clast. $3 \mathrm{HM}-2$, outer rim of clast. $4 \mathrm{HM}-2$, core region of clast. 5 HM-6, outer rim of clast. $6 \mathrm{HM}-6$, core region of clast. $7 \mathrm{HM}-8$, outer rim of clast. $8 \mathrm{HM}-8$, core region of clast.

Subaerial weathering of basalt produces similar elemental distribution patterns to submarine weathering. Singer \& Navrot (1970) examined the alteration of a basalt boulder from the Negev area of southern Israel and found that the alteration is accompanied by an overall depletion of $\mathrm{Mg}, \mathrm{Na}, \mathrm{Ca}, \mathrm{Si}$ and $\mathrm{Mn}$, whereas most other major elements are relatively immobile. Bain et al. (1980) indicated that weathering of Tertiary basalts from Morvern, Scotland involves the depletion of $\mathrm{Si}, \mathrm{Mg}, \mathrm{Ca}$ and $\mathrm{Na}$ and an accumulation of $\mathrm{Al}, \mathrm{Fe}$ and $\mathrm{Ti}$. In addition, these results suggest that element solubility and, therefore, mobility are similar (rate of phase dissolution varies) for both arid (55 $\mathrm{mm}$ annual precipitation, southern Israel) and temperate $(1500 \mathrm{~mm}$ annual precipitation, Morvern, Scotland) climates. For both of these studies, as the effects of weathering increase there is a sympathetic increase in the amount and intensity of iron staining. The alteration of the less stable mafic minerals and glass supplies and transports the required ions and ionic species (cf. Birkeland, 1974; Porter, 1975; Colman \& Pierce, 1981). 
Table 5. Electron microprobe analyses of altered basaltic and tholeiitic rhyolite glasses of this study compared with chemical compositions of basaltic and rhyolite glasses

\begin{tabular}{|c|c|c|c|c|c|c|c|c|c|c|c|c|c|c|}
\hline & 1 & 2 & 3 & 4 & 5 & 6 & 7 & 8 & 9 & 10 & 11 & 12 & 13 & 14 \\
\hline $\mathrm{SiO}_{2}$ & 52.70 & 53.10 & 51.43 & 65.91 & 66.66 & 66.07 & 66.77 & 50.51 & 43.60 & 42.22 & 47.95 & 50.86 & 70.10 & 70.40 \\
\hline $\mathrm{TiO}_{2}$ & 0.11 & 0.09 & 0.02 & 0.12 & 0.61 & 0.22 & 0.61 & 1.89 & 1.61 & 2.22 & 1.75 & 1.87 & 0.49 & 0.80 \\
\hline $\mathrm{Al}_{2} \mathrm{O}_{3}$ & 17.80 & 14.40 & 17.22 & 13.08 & 12.36 & 15.09 & 11.29 & 14.00 & 21.10 & 17.72 & 16.91 & 17.56 & 12.42 & 14.10 \\
\hline $\mathrm{FeO}^{*}$ & 8.70 & 6.50 & 5.75 & 3.86 & 3.71 & 3.41 & 4.78 & 12.19 & 14.00 & 15.64 & a & c & 5.95 & 2.16 \\
\hline $\mathrm{MnO}$ & - & - & 0.12 & 0.03 & 0.16 & 0.12 & 0.06 & n.d. & 0.02 & n.d. & 0.17 & 0.06 & n.d. & 0.11 \\
\hline $\mathrm{MgO}$ & 6.20 & 2.60 & 2.97 & 0.23 & 0.19 & 0.29 & 0.31 & 6.70 & 4.30 & 1.99 & 7.04 & 3.27 & 0.41 & 0.02 \\
\hline $\mathrm{CaO}$ & 2.70 & 2.80 & 2.38 & 2.87 & 2.71 & 2.78 & 2.16 & 11.26 & 1.79 & 0.62 & 11.09 & 3.84 & 3.03 & 1.20 \\
\hline $\mathrm{Na}_{2} \mathrm{O}$ & 2.60 & 2.60 & 2.37 & 3.99 & 1.71 & 3.41 & 1.99 & 2.54 & 0.77 & 2.43 & 2.47 & 2.81 & 4.30 & 2.24 \\
\hline $\mathrm{K}_{2} \mathrm{O}$ & 3.30 & 6.60 & 3.58 & 2.35 & 2.32 & 3.36 & 3.93 & 0.16 & 2.54 & 3.26 & 0.52 & 2.47 & 1.18 & 4.90 \\
\hline $\mathrm{P}_{2} \mathrm{O}_{5}$ & n.d. & n.d. & n.d. & n.d. & n.d. & n.d. & n.d. & 0.15 & n.d. & 0.04 & 0.24 & 0.28 & 0.07 & 0.16 \\
\hline Total & 94.11 & 91.69 & 85.84 & 92.44 & 90.33 & 94.75 & 91.90 & 99.40 & 89.73 & 86.14 & $99.82^{\mathrm{b}}$ & $97.76^{d}$ & 97.95 & 96.10 \\
\hline
\end{tabular}

* Total iron as FeO.

n.d. Not determined.

- Not detected.

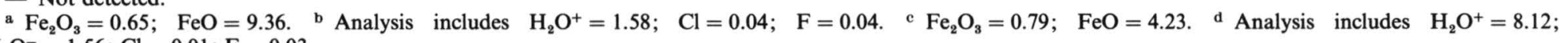
$\mathrm{H}_{2} \mathrm{O}^{-}=1.56 ; \mathrm{Cl}=0.01 ; \mathrm{F}=0.03$.

1 HM-2; clast rim region; altered basaltic glass. $2 \mathrm{HM}-2$; clast core region; altered basaltic glass. $3 \mathrm{HM}-2$. B; clast core region; altered basaltic glass; $n=2$. $4 \mathrm{HM}-2$. A; clast rim region; tholeiitic rhyolite glass; $n=2$. $5 \mathrm{HM}-2$. D; clast core region; tholeiitic rhyolite glass; $n=2$. 6 HM-6. AB; clast rim region; tholeiitic rhyolite glass; $n=4$. $7 \mathrm{HM}-6$. DE; clast core region; tholeiitic rhyolite glass; $n=4$. 8 P44-66NI; Pacific Ocean; unaltered basaltic glass (Melson et al. 1975). 9 DSDP Leg 2 site 10; altered basaltic glass (Thompson, 1973). 10 5-39-2-CC; palagonite (Melson, 1973). 11 Green glass (unaltered), Hound Island Volcanics, Alaska (Muffler et al. 1969). 12 Brown glass (altered) derived from green glass, Hound Island Volcanics, Alaska (Muffler et al. 1969). 13 PO2.7ONI; soda rhyolite (Melson et al. 1975). 14 72-20GL; tholeiitic rhyolite glass, McKinney Basalt, Idaho (Leeman \& Vitaliano. 1976). 
Comparison of glass analyses 1-7 of Table 5 with the chemical analyses of fresh and utered basalt and tholeiitic rhyolite glasses suggests that the altered interstitial basaltic glass of this study, whether from a weathered clast rim or less weathered clast core, resembles attered (palagonitized) basalt glass. Differences in the $\mathrm{SiO}_{2}$ content, higher for the altered dlass of this study, and lower $\mathrm{TiO}_{2}$ and total iron contents cannot be adequately evaluated. However, the intersertal basaltic glass in plagioclase has a similar $\mathrm{SiO}_{2}$ and total iron content, yet significantly, higher $\mathrm{MnO}$ and lower $\mathrm{TiO}_{2}$ contents than either fresh or altered basaltic glass. The lack of fresh basaltic glass for the Antarctic specimens precludes further comparison. The sodic rhyolite glass from submarine basalts (Melson et al. 1975) and tholeiitic rhyolitic glass from the Snake River Plain, Idaho (Leeman \& Vitaliano, 1976) compare favourably with analyses of tholeiitic rhyolite residual glass of this study.

\section{ic. Interpretation}

The active participation of the silicate mineral phases in rind production appears minimal. Rather, the breakdown of the glass phases, particularly the interstitial and intersertal basaltic glasses, due to hydration-oxidation processes appears to be dominant. The change inzone colour from pale green to deep red and an increase in colour density occur probably because of the hydration and accumulation of basaltic glasses and iron oxides, respectively.

The development of Zone 5, most weathered, is suggested to be the last zone to form before mechanical weathering processes take over. Subsequent to Zone 5 development, the less stable basaltic glass cement disaggregates, leaving aeolian and freeze-thaw processes to remove the loose mineral grains and fragments from the outer surface of the clasts. Inspection of Figures 2 and 5 shows a direct correlation of Zone 5 thickness with the geomorphic character of the clasts. We interpret this correlation to indicate that a critical thickness value of approximately $0.5 \mathrm{~mm}$ must, in general, be attained before disaggregation and soil material production can be achieved.

The stepwise increase in Zone 5 thicknesses (Fig. 3b) was discussed by Talkington, Gaudette \& Mayewski (1976). Briefly, if the distance from the source area is directly related to the time of spalling from the source dike, then the sympathetic increase of zone thickness with distance from source for both Zones 4 and 5 (Fig. 3) suggests that the weathering processes are accumulative.

\section{Glacio-geomorphic implications}

Glacial deposits found in the Queen Maud Mountains record four periods of glaciation (Mayewski, 1975; Mayewski \& Goldthwait, in the Press) and several exposures of glacial deposits occur near Halfmoon Bluff (Table 6). The regional and local ice surface levels in existence during these glaciations and the dating of the glaciations by correlation with dated glaciations farther north along the Transantarctic Mountains have been determined by Mayewski (1975) and Mayewski \& Goldthwait (in the Press).

The 1900 m elevation of the study site places it at the upper limit of the Scott Glaciation level and below the Queen Maud Glaciation level. During the Queen Maud Glaciation rock surfaces in the area have been highly eroded, making it likely that the basalt clasts at Halfmoon Bluff would have been removed. The first of the clasts would have been exfoliated from the source dike during the interglacial periods between the Queen Maud and Scott glaciations. Descriptions of the surface weathering on the most weathered of the basalt clasts are comparable to surface weathering described by Mayewski \& Goldthwait (in the Press) on clasts exposed on the surface of Scott and/or Queen Maud deposits. Thus the maximum duration of the subaerial exposure of these clasts is approximately 4.2 Ma B.P. 

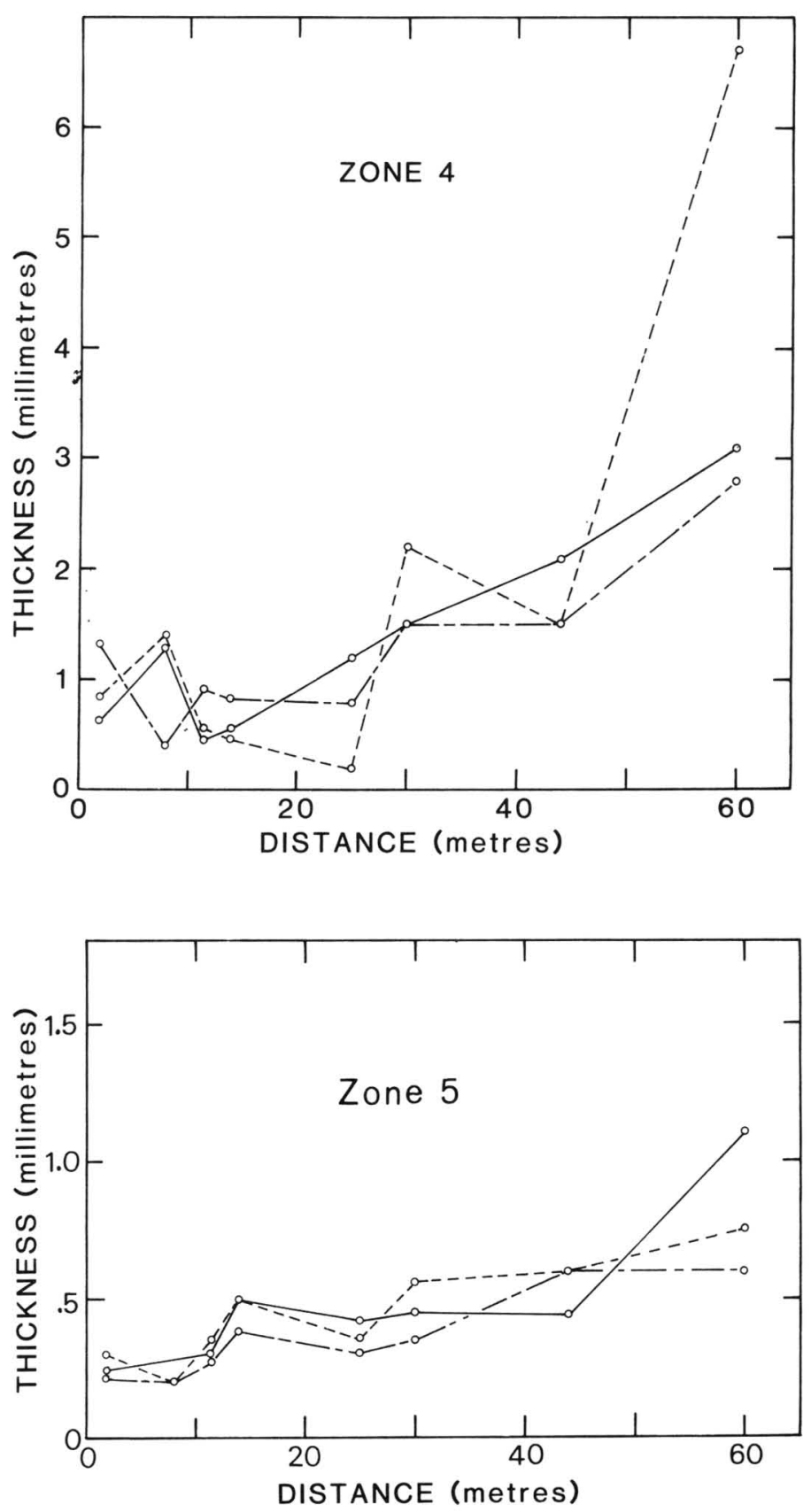

Figure $3 \mathrm{a}$, b. Zones 4 and 5, top, bottom and side thicknesses plotted as a function of distance from ridge crest. Top - solid line; bottom - long dash, short dash; side - short dash (from Talkington, Gaudette \& Mayewski, 1976). 
Table 6. Elevations of deposits recording glacial events in the Queen Maud Mountains that are close to Halfmoon Buff (from Mayewski \& Goldthwait, in the Press)

\begin{tabular}{|c|c|c|c|c|}
\hline \multicolumn{5}{|c|}{ Elevation $(\mathrm{m})$ at top of deposit listed by glaciation (age) } \\
\hline Location & $\begin{array}{c}\text { Amundsen } \\
(<9490 \text { y. B.P. })\end{array}$ & $\begin{array}{l}\text { Shackleton } \\
(>0.049 \text { to } \leqslant 1.6 \\
\text { Ma B.P. })\end{array}$ & $\begin{array}{c}\text { Scott } \\
(\geqslant 2.1 \text { to } \leqslant 2.7 \\
\text { Ma B.P. })\end{array}$ & $\begin{array}{l}\text { Queen Maud } \\
\text { (> 4.2 Ma B.P.) }\end{array}$ \\
\hline Bennet Platform & 1560 & 1700 & 1840 & 2150 \\
\hline Half Century Nunatak & - & - & - & 2600 \\
\hline Southern Cumulus Hills & 1900 & 2150 & $>2230$ & - \\
\hline Landry Bluff & 1650 & - & 1900 & - \\
\hline Mount Kenyon & 1430 & 1630 & 1820 & - \\
\hline
\end{tabular}

Assuming that downslope transport has never ceased and has been constant since the original subaerial exposure, approximately 4.2 Ma B.P., of the source dike the downslope velocity over the $60 \mathrm{~m}$ slope, for the frontal clasts in the study area, is $1.4 \times 10^{-3} \mathrm{~cm} \cdot \mathrm{y}^{-1}$. This value is the minimum downslope velocity $\left(V_{m}\right)$ in the study area. The theoretical downslope velocity $\left(V_{c}\right)$ in the study area can be estimated, assuming the transport is due only to creep, by using Scheidegger's (1970) equation for the determination of non-lateral creep velocity of the rock material due to thermal expansion. The primary variables in this relationship are specified by climate, thus the departure from $V_{m}$ to $V_{c}$ could be related to other factors, particularly a change in climate.

Creep, due to heating and cooling of the sediments underlying the basalt clasts, has already been suggested to be the most effective mechanism of mass wasting in the study area. The velocity of this downslope transport can be determined (Scheidegger 1970, p. 102) if:

(1) thermal expansion of the rock material occurs when temperatures are above $0{ }^{\circ} \mathrm{C}$;

(2) temperature fluctuations during any one cycle are harmonic;

(3) the slope is long relative to its width and is straight;

(4) all material is constrained from movement parallel to the slope.

The downslope creep velocity $\left(V_{c}\right.$ in $\left.\mathrm{cm} \cdot \mathrm{y}^{-1}\right)$ operating in the study area is:

$$
V_{c}=3 \kappa \tan \beta \delta T_{0} \sqrt{ }\left[k /\left(\tau \pi \rho c_{p}\right)\right]
$$

where: $\kappa=$ average linear expansion coefficient of rock (from Skinner, 1966, p. 94, sandstone and mudstone $=8 \times 10^{-6} \cdot{ }^{\circ} \mathrm{C}^{-1}$ for temperatures near $20^{\circ} \mathrm{C}$ ); $\beta=$ average slope angle (for study area $\left.=15.2^{\circ}\right) ; \delta T_{0}=$ maximum rock surface temperature difference (from Goldthwait, written comm., 1972, aplite $=11^{\circ} \mathrm{C}$, used as an approximation of sandstone-mudstone due to similar albedo and thermal conductivity); $k=$ thermal conductivity of rock (from Clark, 1966, p. 462 average of sandstone and mudstone $=5.2 \times 10^{-3} \mathrm{cal} . \mathrm{cm}^{-1} \cdot \mathrm{sec}^{-1} .{ }^{\circ} \mathrm{C}$ ); $\tau=$ period of cycle (from Goldthwait, written comm., 1972, for temperature fluctuations above $0^{\circ} \mathrm{C}=18 \mathrm{cy} \cdot \mathrm{y}^{-1}=1.752 \times 10^{6} \mathrm{sec}$ ); $\rho=$ average rock density (from Daly et al. 1966, p. 23, average for sandstone and mudstone $=2.4 \mathrm{~g} . \mathrm{cm}^{-3}$ ); $c_{p}=$ specific heat of rock (from Handbook of Chemistry and Physics, 1972 , p. D-138, value for silicon $=0.157 \mathrm{cal} . \mathrm{g}^{-1} \cdot{ }^{\circ} \mathrm{C}^{-1}$ by linear extrapolation of values at $100 \mathrm{~K}$ and $25^{\circ} \mathrm{C}$ ).

Estimates of $\left(\delta T_{0}\right.$ and $\left.\tau\right)$ come from unpublished data collected from 10 November to 20 December 1963, by Goldthwait in the Queen Maud Mountains. During this period he measured air temperatures and rock surface temperatures for several different lithologies on a daily basis. Hourly observations were made on 24 November 1963. Data from Goldthwait's study provide an estimate of the current $\delta T_{0}$ and $\tau$ for the Queen Maud 
Table 7. Various values of non-lateral flow velocity due to dry creep

\begin{tabular}{ccc}
\hline$V\left(\mathrm{~cm} \cdot \mathrm{y}^{-1}\right)$ & $\delta T_{0}\left({ }^{\circ} \mathrm{C}\right)$ & $\tau\left(\mathrm{cy} \cdot \mathrm{y}^{-1}\right)$ \\
\hline $1.13 \times 10^{-1}\left(V_{c}\right)$ & 11 & 18 \\
$2.7 \times 10^{-2}\left(V_{1}\right)$ & 11 & 1 \\
$1.13 \times 10^{-2}\left(V_{2}\right)$ & 1.1 & 18 \\
$2.7 \times 10^{-3}\left(V_{3}\right)$ & 1.1 & 1 \\
$1.3 \times 10^{-3}\left(V_{4}\right)$ & 0.5 & 1 \\
\hline
\end{tabular}

Mountains. Using these values in equation (1), the non-lateral flow velocity due to dry creep is $V_{c}=1.13 \times 10^{-1} \mathrm{~cm} \cdot \mathrm{y}^{-1}$. Several different values of $\delta T_{0}$ and $\tau$ were substituted in the equation (Table 7) in order to arrive at a value close to the value of $V_{m}=1.4 \times 10^{-3} \mathrm{~cm} \cdot \mathrm{y}^{-1}$ derived empirically.

The value for $V_{4}$ of $1.3 \times 10^{-3} \mathrm{~cm} \cdot \mathrm{y}^{-1}$ comes closest to $V_{m}$. The $V_{4}$ value was arrived at by reducing maximum rock surface-temperature difference $\left(\delta T_{0}\right)$ to $0.5^{\circ} \mathrm{C}$ and the period of the heating and cooling cycle to $1 \mathrm{cy} . \mathrm{y}^{-1}$. Comparison of these values suggests that during all or part of the time that mass wasting affected the study slope air temperature fluctuations and, hence, rock surface-temperature fluctuations were very small and temperatures rarely, if ever, rose above $0^{\circ} \mathrm{C}$. These estimates provide only a speculative approximation of the former climate affecting the study area. Several problems require either further characteri. zation or validation before these results can be accepted. These problems revolve around the knowledge of: (1) the spatial and temporal distribution of snow and ice patches in the study area; (2) whether mass wasting has constantly affected the study area or perhaps only during interglacial periods; and (3) the mode of mass wasting (decreasing and/or increasing constant, linear and/or geometric modes).

\section{Conclusions}

Chemical analyses of the sample suite suggest that the production of weathering rinds occurs by oxidation-hydration processes which affect the glass, principally the basaltic glass, more strongly than the minerals. The longer these chemical processes are operative, the more intense, accumulative and penetrative is rind development. A critical value of approximately $0.5 \mathrm{~mm}$ for Zone 5 must be obtained before physical processes (i.e. aeolian and freeze-thaw) disaggregate the outer surface of the basalt clast and produce soils.

The elevation of the study site and comparison of the surface weathering on the basalt clasts in the study area with surface weathering on basalt clasts dated by association with glacial deposits in the Transantarctic Mountains suggests that the clasts in the study are have probably been exposed to surface weathering for as long as $4.2 \mathrm{Ma}$. Mass wasting rates as low as $1.4 \times 10^{-3} \mathrm{~cm} \cdot \mathrm{y}^{-1}$ have been computed using glacial geologically determined age for the surface weathering. Assuming that creep due to heating and cooling is the only mass wasting mechanism operating in the study area today, current rates of mass wasting are estimated to be $1.13 \times 10^{-1} \mathrm{~cm} \cdot \mathrm{y}^{-1}$. The difference in the two computed rates can be explained by assuming that: (1) snow and/or ice covered the study area for a large portion of the last $4.2 \mathrm{Ma}$; or (2) rock-surface to air temperature differences were as little as $0.5^{\circ} \mathrm{C}$ and heating and cooling cycles were as few as $1 \mathrm{cy} \cdot \mathrm{y}^{-1}$ for the last $4.2 \mathrm{Ma}$. The formeris unlikely since the surfaces of the basalt clasts display weathering characteristics similar to samples exposed as long as $4.2 \mathrm{Ma}$. The latter suggestion is more likely, indicating that temperatures in the study area over the last $4.2 \mathrm{Ma}$ have been $0^{\circ} \mathrm{C}$ or below and that temperature fluctuations have been very minor. 
Acknowledgements to H. Williams and C. Lynas (Memorial University of Newfoundland) and D. Watkinson (Carleton University) for help with the manuscript. Sample collection was made possible by NSF Grant GA-4029, administered to P.A.M. while formerly at the Institute of Polar Studies, Ohio State University. Laboratory facilities were provided by the Department of Earth Sciences, University of New Hampshire and the Department of Geology, Memorial University of Newfoundland.

\section{References}

Bain, D. C., Ritchie, P. F. S., Clark, D. R. \& Duthie, D. M. L. 1980. Geochemistry and mineralogy of weathered basalt from Morvern, Scotland. Mineralog. Mag. 43, 856-76.

Birkeland, P. W. 1974. Pedology, Weathering and Geomorphological Research. New York: Oxford University Press.

Bull, C. 1971. Snow accumulation in Antarctica. In Research in the Antarctic (ed. L. Quam), Am. Assoc. Adv. Sci. 367-421.

Claridge, G. G. C. \& Campbell, I. B. 1968. Soils of the Shackleton Glacier region, Queen Maud Range. N.Z. J. Sci. 11, 171-218.

Clark, S. P., Jr. 1966. Thermal conductivity. In Handbook of Physical Constants (ed. S. P. Clark, Jr.), Mem. geol. Soc. Am. 97, 461-82.

Colman, S. M. \& Pierce, K. L. 1981. Weathering rinds on andesitic and basaltic stones as a Quaternary age indicator. Western United States. Prof. Pap. U.S. geol. Surv. 1210.

Cooke, R. U. \& Smalley, I. J. 1968. Salt weathering in deserts. Nature, Lond. 220, 1226-7.

Daly, R. A., Manger, G. E. \& Clark, S. P., Jr. 1966. Density of rocks. In Handbook of Physical Constants (ed. S. P. Clark, Jr.), Mem. geol. Soc. Am. 97, $20-6$.

Finger, L. W. \& Hadidiacos, C. G. 1972. Electron microprobe automation. Yb. Carnegie Instn Wash. 71, 591-600.

Fritz, S. J. \& Ragland, P. C. 1980. Weathering rinds developed on plutonic igneous rocks in the North Carolina Piedmont. Am. J. Sci. 280, 546-59.

Handbook of Chemistry and Physics, 1973 (ed. R. C. Weast). Cleveland, Ohio: Chemical Rubber Co. Press.

Jackson, T. A. \& Keller, W. D. 1970. A comparative study of the role of lichens and 'inorganic' processes in the chemical weathering of recent Hawaiian lava flows. Am. J. Sci. 269, 446-66.

Leeman, W. P. \& Vitaliano, C. J. 1976. Petrology of McKinney Basalt, Snake River Plain, Idaho. Bull. geol. Soc. Am. 87, 1777-92.

Mayewski, P. A. 1975. Glacial geology and Late Cenozoic history of the Transantarctic Mountains, Antarctica. Institute of Polar Studies Report 56, The Ohio State University.

Mayewski, P. A. \& Goldthwait, R. P. (in the Press). The glacial history of the Transantarctic Mountains: a record of the East Antarctic ice sheet. In Transantarctic Mountains (ed. J. Spelettstoesser and M. Turner). Am. Geophys. Union Spec. Vol.

Melson, W. G. 1973. Basaltic glasses from the Deep Sea Drilling Project: chemical characteristics, compositions of alteration products, and fission track 'ages'. EOS 54, 1011-14.

Melson, W. G., Thompson, G., Vallier, T. L., Wright, T. L., Beyerly, G. \& Nelen, J. 1975. Chemical diversity of abyssal volcanic glass erupted along Pacific, Atlantic and Indian Ocean sea-floor spreading centers. Wollard Symp. Vol., Geophys. Res., Monograph series.

Muffler, L. J. P., Short, J. M., Keith, T. E. C. \& Smith, V. C. 1969. Chemistry of fresh and altered basaltic glass from the Upper Triassic Hound Island Volcanics, southeastern Alaska. Am. J. Sci. 267, 196-209.

Porter, S. C. 1975. Weathering rinds as a relative-age criterion: application to subdivision of glacial deposits in the Cascade Range. Geology 3, 101-4.

Scheidegger, A. E. 1970. Theoretical Geomorphology. Berlin: Springer-Verlag.

Singer, A. \& Navrot, J. 1970. Diffusion rings in altered basalt. Chem. Geol. 6, 31-41.

Skinner, B. J. 1966. Thermal expansion. In Handbook of Physical Constants (ed. S. P. Clark, Jr.). Mem. geol. Soc. Am. 97, 78-96.

Talkington, R. W., Gaudette, H. E. \& Mayewski, P. A. 1976. Preliminary investigation of the 
weathering stages of a tholeiitic basalt (dolerite), Queen Maud Mountains, Antarctica. Antarctic J. 14, 242-5.

Thompson, G. 1973. A geochemical study of the low-temperature interaction of sea-water and oceanic igneous rocks. EOS 54, 1015-19.

Weyant, W. S. 1967. The Antarctic atmosphere: climatology of the surface environment. Am. Geo. Soc. Folio 8.

R.W.T.

Department of Geology

Carleton University

Ottawa, Ontario

Canada K1S 5B6

Present address

Geology Department

Stockton State College

Pomona, New Jersey

U.S.A. 08240
P. A. M. \& H. E. G.

Department of Earth Sciences University of New Hampshire Durham, New Hampshire U.S.A. 03824

\section{Appendix}

All silicate mineral analyses were done on an MAC automated microprobe at the Department of Earth and Planetary Sciences, MIT, Cambridge, MA. Operating conditions for the probe for silicate analyses were $15 \mathrm{kV}$ accelerating voltage, sample current $0.03 \mu \mathrm{A}$, counting time $30 \mathrm{sec}$ and beam diameter of about $2 \mu \mathrm{m}$. Mineral standards similar in composition to the silicate phases were used.

Glass analyses were done on a JEOL automated electron microprobe at the Department of Geology, Memorial University of Newfoundland, St John's, Newfoundland, equipped with an automated system (KRIESEL) using a PDP 11/20 minicomputer. Data have been reduced on line using the Geolab program of Finger \& Hadidiacos (1972). Operating conditions were $15 \mathrm{kV}$ accelerating voltage, sample current $0.03 \mu \mathrm{A}$, counting time $30 \mathrm{sec}$ and a defocused beam of about $50 \mu \mathrm{m}$ diameter. Basalt glass standard VG-2 (Melson et al. 1975) was used for comparison.

Accuracy at both facilities for all elements is $( \pm) 2$ weight $\%$, except for $\mathrm{Na}$ and $\mathrm{K}$ for which it is $( \pm) 5$ weight $\%$.

\section{EXPLANATION OF PLATES}

Plate 1. Location ( $85^{\circ} 13^{\prime} \mathrm{S}$ lat., $175^{\circ} 30^{\prime} \mathrm{E}$ long.) and aerial view (U.S. Navy photo TMA 1006,227 , F31) of Cumulus Hills and Shackleton Glacier looking west. Study area marked by arrow (from Talkington, Gaudette \& Mayewski, 1976, p. 243).

Plate 2a. Photomicrograph of diabasic texture (specimen HM-2); Symbols: C, chlorite; CPX, clinopyroxene; $G$, interstitial basaltic glass; $P$, plagioclase. Transmitted light; scale bar equals $0.13 \mathrm{~mm}$.

Plate $2 \mathrm{~b}$. Photomicrograph of intersertal basaltic glass $(\mathrm{G})$ in plagioclase (P) (specimen HM-2). Note iron oxides in interstitial basaltic glass (IG). Transmitted light; scale bar equals $0.04 \mathrm{~mm}$. 
Geol. Mag. Vol. 119, 1982, Talkington, Mayewski \& Gaudette, Plates 1-2, between pp. 566 and 567.

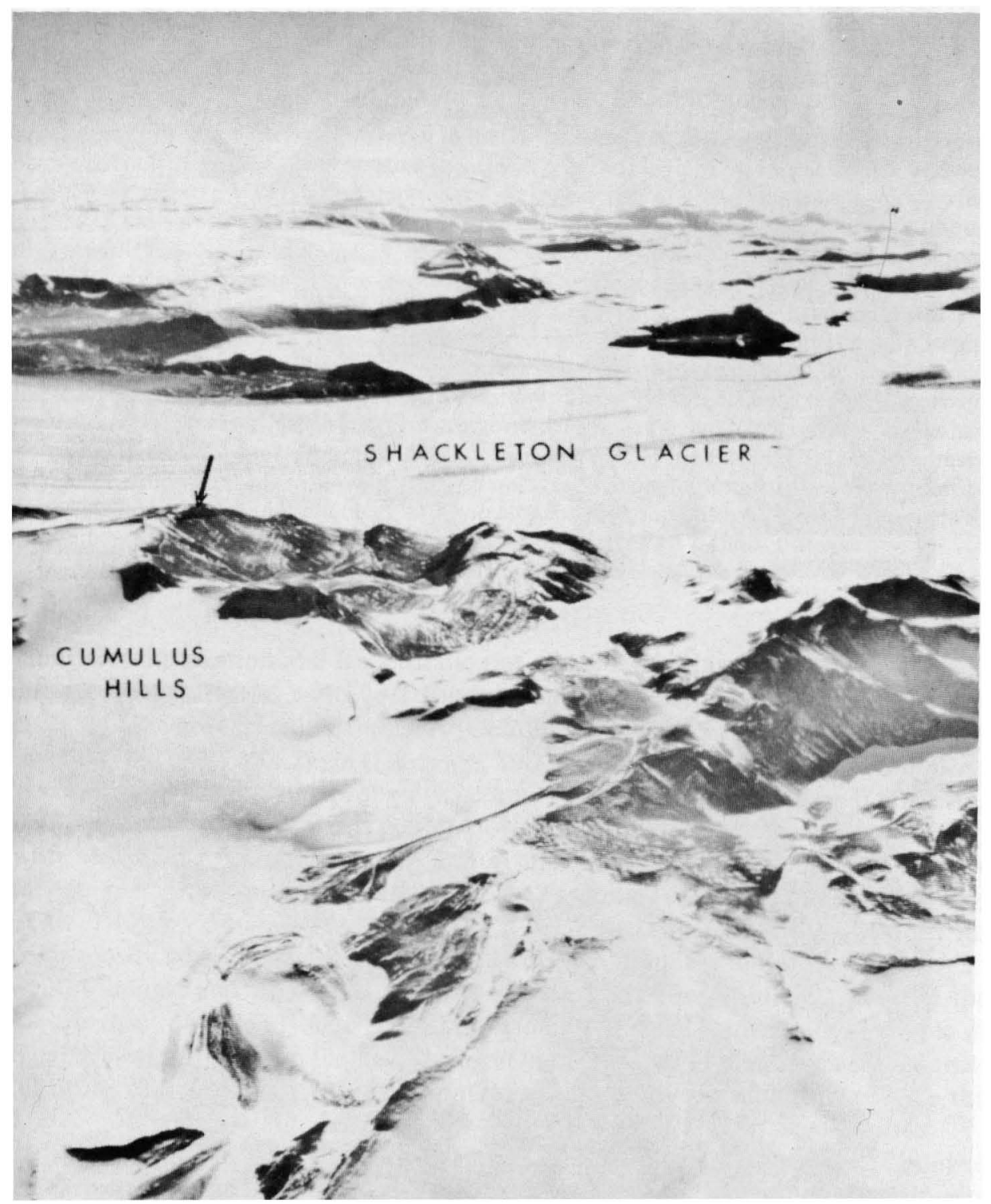

Plate 1. Cumulus Hills and Shackleton Glacier. 
Geol. Mag. Vol. 119, 1982, Talkington, Mayewski \& Gaudette, Plate 2.

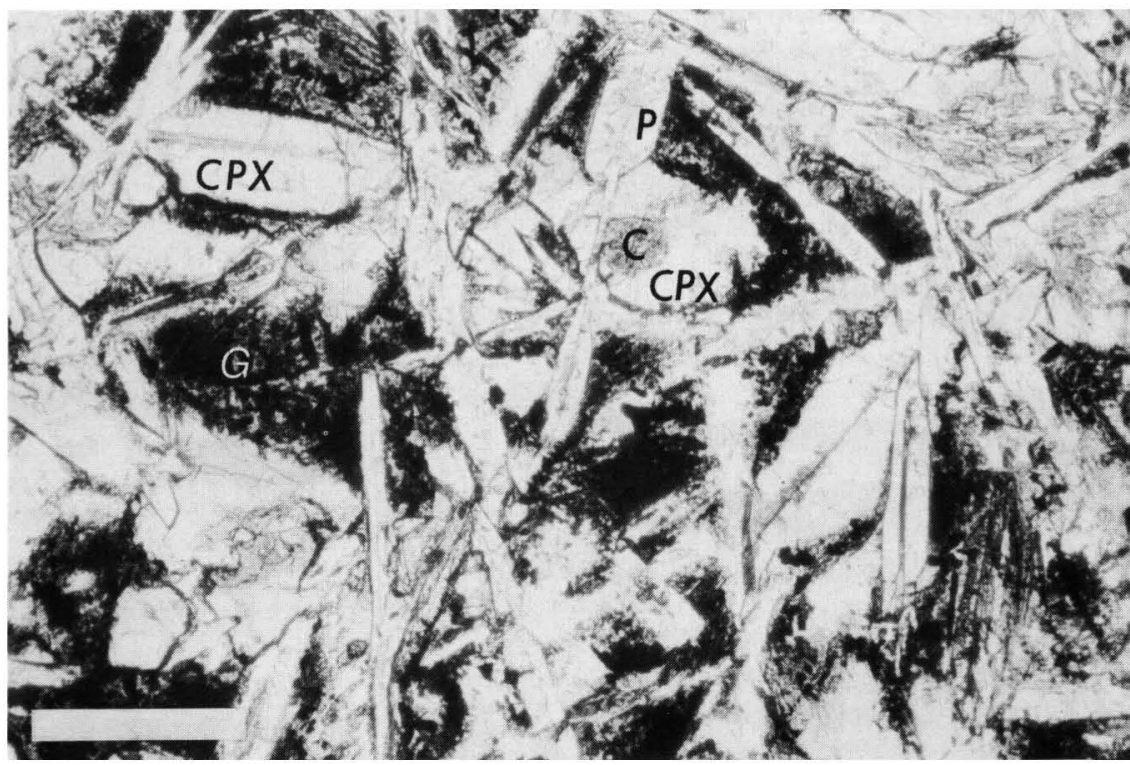

a

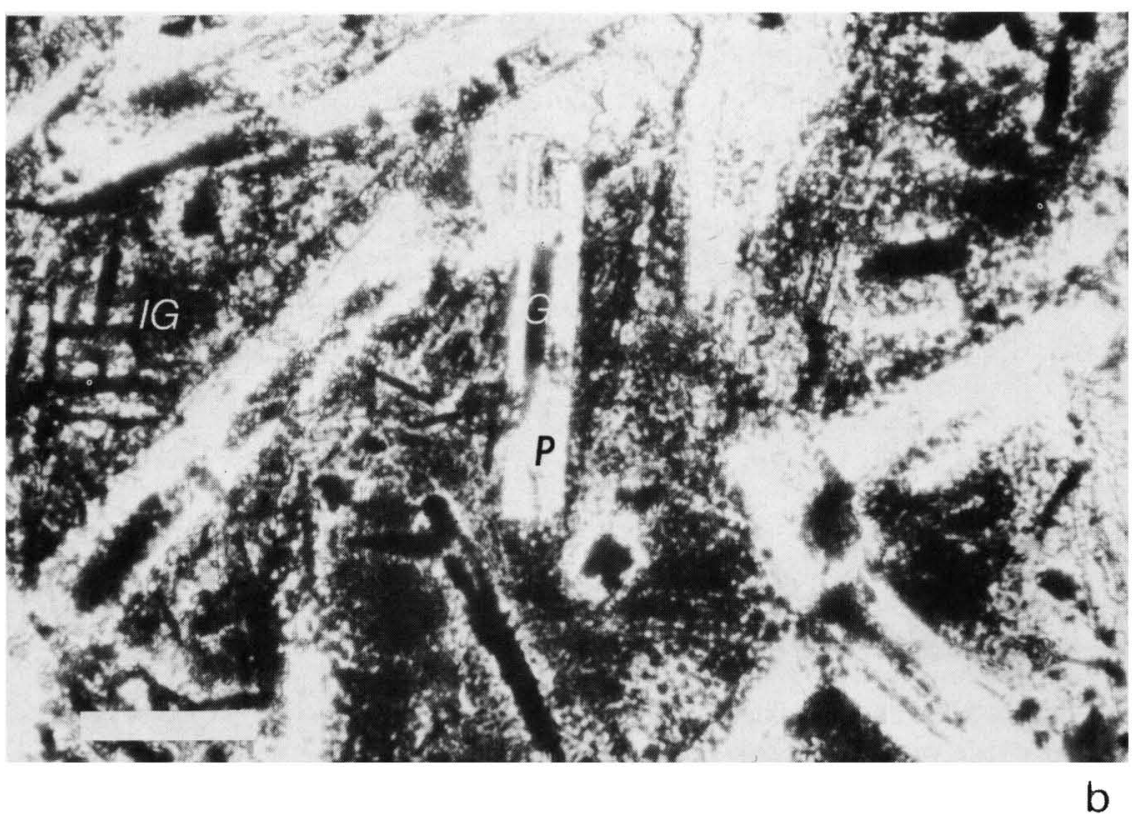

Plate 2. Photomicrographs: (a) diabasic texture, (b) intersertal basaltic glass. 